\title{
Use of Vitamins and their Derivates in the Treatment of Cutaneous Disorders
}

\author{
Andrea Chiricozzi ${ }^{1,2,{ }^{*}}$, Maria Sole Chimenti ${ }^{3}$, Mauro Bavetta ${ }^{1}$, Graziella Babino ${ }^{1}$, \\ Sergio Chimenti ${ }^{1}$ and Rosita Saraceno ${ }^{1}$ \\ ${ }^{1}$ Department of Dermatology, University of Rome Tor Vergata. Viale Oxford 81, 00133, Rome, Italy \\ ${ }^{2}$ Laboratory for Investigative Dermatology, The Rockefeller University, 1230 York Avenue, Box 178, New \\ York, New York 10065-6399, USA \\ ${ }^{3}$ Department of Rheumatology, University of Rome Tor Vergata. Viale Oxford 81, 00133, Rome, Italy
}

\begin{abstract}
Vitamins represent fundamental substrates for various physiologic functions occurring in human body. This review seeks to highlight their relevance in skin biology and to describe the cutaneous manifestations correlated with their deficiency.
\end{abstract}

Keywords: Vitamin deficiency, psoriasis, vitamin A, vitamin B, vitamin C, skin physiology.

\section{INTRODUCTION}

The intake and the metabolism of nutrients in appropriate proportion provide the substrates necessary for physiologic functions. Derangements of this normal proportion and balance lead to disease states that can produce cutaneous manifestations with an involvement of multiple organs [1]. Because of the importance of nutrients for cellular metabolism in a variety of tissues, this review provides an overview on vitamins and their role in cutaneous disorders.

\section{VITAMIN A}

Vitamin A, retinol, is a fat-soluble vitamin that is required for retinal photoreceptor function, hematopoiesis, embryonic development, skin cell differentiation, immune system function and gene transcription. Vitamin A cannot be synthesized; it must be obtained through animal products, such as cow's milk, liver, eggs, fish oils, as retinyl esters. Retinyl esters are converted to retinol and absorbed in the ileum. After absorption, a small percentage of retinol is converted to its biologically active form, all-trans retinoic acid (tretinoin), through an intermediary, retinaldehyde. Most of retinol is converted to retinyl ester, its storage form [1, 2]. Two vitamin A derivates, namely retinal and retinoid acid, are used for therapeutic purposes.

Retinoid signaling is mediated by various nuclear receptors, which belong to superfamily of nuclear

\footnotetext{
*Address correspondence to this author at the Department of Dermatology, University of Rome Tor Vergata, Viale Oxford 81, 00133, Rome, Italy;

Tel: +39.06.20902742; Fax: +39.06.20902743;

E-mail: chiricozziandrea@gmail.com
}

receptors that act as transcription factors, which promote the physiologic effects on DNA transcription. These receptors fall into two classes, the retinoic acid receptor (RARs) and the retinoid $x$ receptor (RXRs). Human skin expresses predominantly RAR-y and RXR$\alpha$ [3-5].

Vitamin A deficiency is the most common cause of preventable childhood blindness. Xerophthalmia is initially characterized by defective dark adaptation and night blindness. Perpetuating vitamin A deficiency determinates xerosis, ulceration and perforation of the cornea, prolapse of the iris, and, ultimately, blindness $[6,7]$. The typical cutaneous hypovitaminosis A manifestation is phrynoderma, characterized by xerosis and keratotic follicular papules preferably located on the flexure and traction side of the upper arms, and on the trunk and nape (Table 1). Differential diagnoses include pityriasis rubra pilaris and lichen spinulosus. Phrynoderma is probably based on additional deficiencies of unsaturated fatty acids, vitamin $\mathrm{C}$, and B-complex vitamins [8-13].

Vitamin A and its analogs in cosmetic applications are among the most important agents used for skin care. They have been used topically in treating acne and photodamage skin and they have been tested for the topical treatment of striae, cellulitis, and wound healing [14-20]. In addition, they represent an approved and well-established treatment for psoriasis, used both orally and topically as monotherapy or in therapeutic combinations.

\section{Use of Retinoids in the Treatment of Acne}

Acne is a common skin disease showing a multifactorial pathogenesis, which includes increased 
Table 1: Disorders and Clinical Manifestions Related to Vitamin Deficiency

\begin{tabular}{|c|c|}
\hline Vitamins & Disorders associated with vitamin deficiency \\
\hline BETA-CAROTENE & Immunosuppression \\
\hline VITAMIN B2 & $\begin{array}{l}\text { Ariboflavinosis (angular cheilitis, pharyngitis, glossitis, seborrheic dermatitis, photosensitivity), Oro-oculo-genital } \\
\text { syndrome }\end{array}$ \\
\hline VITAMIN B6 & $\begin{array}{l}\text { Seborrheic eruption, Oral symptoms (glossitis, stomatitis, cheilitis, aphtha), Conjunctivitis, Intertrigo, Pellagra- } \\
\text { like dermatitis (erythema, hyperpigmentation, scaling), Neurologic symptoms (somnolence, confusion, } \\
\text { peripheral neuropathy), Hypochromic, microcytic anemia }\end{array}$ \\
\hline VITAMIN B12 & $\begin{array}{l}\text { Megaloblastic anemia, Hypersegmented neutrophils, Cutaneous hyperpigmentation, Mucocutaneous } \\
\text { manifestations (angular cheilitis, Hunter glossitis, localized or diffuse hair depigmentation, mucocutaneous } \\
\text { hyperpigmentation), Neurologic signs (paresthesias, ataxia, symmetric loss of vibration and proprioception, } \\
\text { severe weakness, spasticity, paraplegia, apathy, somnolence, irritability, memory loss, dementia) }\end{array}$ \\
\hline VITAMIN D & Osteomalacia, Rickets \\
\hline VITAMIN E & $\begin{array}{l}\text { Abetalipoproteinemia (poor transmission of nerve impulses, muscle weakness, retina degeneration), } \\
\text { Neurolomuscolar signs (spinocerebellar ataxia, myopathies, dysarthria, absence of deep tendon reflexes, loss } \\
\text { of vibratory sensation and proprioception), Anemia, Ocular diseases (retinopathy, cataracts), } \\
\text { Immunosuppression, Male infertility, Dry hair or loss of hair }\end{array}$ \\
\hline VITAMIN K & $\begin{array}{l}\text { Multiorgan hemorrhage (cutaneous, gastrointestinal, genitourinary, and retroperitoneal bleeding), Purpura and } \\
\text { ecchymosis, Impaired wound heeling, Immunosuppression, Neonatal vitamin K deficiency bleeding (VKDB) }\end{array}$ \\
\hline
\end{tabular}

secretion of sebum, follicular hyperkeratinization, bacterial colonization by Propionibacterium acnes ( $P$. acnes), and a potent inflammatory response. Retinoids might be considered as the ideal agents for treating acne because they are able to interfere with the majority of pathogenic aspects having (i) antiinflammatory effects, (ii) reducing seborrhea, (iii) regulating keratinocyte proliferation and differentiation.

Retinoids, in particular trans-retinoic acid (tretinoin) as topical formulation, have been used to treat acne since 1974 [21]. The principal Vitamin A metabolite used for the treatment of acne is isotretinoin (13-Cis retinoic acid). Isotretinoin regulates keratinocyte proliferation leading to a reduction of comedone formation (Table 2). It also suppresses sebaceousgland activity with a subsequent reduction of sebum production, which hampers $P$. acnes colonization. Because of this activity, isotretinoin is also successfully used in oral formulation for the management of severe nodulocystic acne [22-25].

\section{Use of Retinoids in the Treatment of other Cutaneous Disorders}

Vitamin $A$ and its derivatives, etretinate and isotretinoin, have been proved effective in the treatment of keratinizing disorders such as hidradenitis suppurativa, Darier's disease, granulomatous rosacea, lamellar ichthyosis, and non-bullous congenital ichthyosiform erythroderma [26,27]. Several studies reported that oral isotretinoin might induce extended remission or cure of pityriasis rubra pilaris [28-30]. Qui vanno divise: nel punto [A] va messa la referenza 26 e 28 mentre nel punto [B] vanno messe la referenza 27 , 29, e 30 .

Retinoic acid and retinol are involved in the repair of photodamage by a restorative mechanism and by limiting the progression of existing damage. In particular, they inhibit the UV-induced expression of the matrix metalloproteinases, which are responsible for the breakdown of collagen fibers in the dermis. Retinoic acid regulates keratinocyte proliferation and differentiation resulting in a physiological shedding of mature keratinocytes and in smoother skin-surface texture. Moreover, it stimulates fibroblasts in producing abundant collagen, which reconstitutes regular dermal thickness and more resistance to trauma $[14,15]$.

Regarding pigmentation, retinoids also inhibit UVinduced alterations constituted by brownish spots and overall uneven pigmentation. 
Table 2: Functions and Effects of Vitamins on Skin Physiology

\begin{tabular}{|c|c|}
\hline \multicolumn{2}{|c|}{ Effects of vitamins on cutaneous physiologic processes } \\
\hline $\begin{array}{l}\text { VITAMINA B COMPLEX: VIT. B1 (THIAMIN), VIT. } \\
\text { B2 (RIBOFLAVIN), VIT. B3 (NIACIN), VIT. B6 }\end{array}$ & $\begin{array}{l}\text { - metabolic and oxidation-reduction reactions } \\
\text { - stabilization and protection of cell membrane }\end{array}$ \\
\hline VITAMIN C & $\begin{array}{l}\text { - protection against UV-induced DNA damage and lipid peroxidation } \\
\text { - formation of stratum corneum barrier lipids } \\
\text { - normalization of epidermal lipid formation } \\
\text { - regulation of collagen production, fibroblast responses and white } \\
\text { cell production (scar tissue formation) } \\
\text { - defense against infection (boosting immune response) }\end{array}$ \\
\hline VITAMIN D & $\begin{array}{l}\text { - inhibition of keratinocyte proliferation } \\
\text { - induction of keratinocyte differentiation } \\
\text { - modulation of the cutaneous immune system }\end{array}$ \\
\hline VITAMIN E & $\begin{array}{l}\text { - anti-inflammatory action } \\
\text { - protection from UV light-induced long-term damages } \\
\text { - reduction of sebum production in seborrheic skin } \\
\text { - regulation of scar tissue formation (accelerating wound healing) }\end{array}$ \\
\hline VITAMIN K & $\begin{array}{l}\text { - wound healing process } \\
\text { - defense against pathogens }\end{array}$ \\
\hline
\end{tabular}

Tretinoin was proved effective in ameliorating photo-induced damaging in experimental models, reflecting the efficacy of topical tretinoin in promoting natural reparative processes in photodamaged skin [31-33].

Striae, or stretch marks, can be treated with alltrans retinoic acid, which may fully or partially reverse the progression of stretch marks and decrease their length and width in $80 \%$ of patients. $[17,18]$.

Cellulitis is characterized by areas of irregular contours with round depressions, often described as orange-peel or dimpled skin. This aspect is the result of irregular fat aggregates and both lymphatic-and connective-tissue anomalies. Retinol has been reported to improve this cosmetic defect [19]

Synthetic retinoids such as tretinoin, isotretinoin, and etretinate have been studied in many premalignant and malignant skin conditions, such as actinic keratoses, squamous cell carcinomas, Bowen's disease, basal cell carcinomas, keratoacanthomas, porokeratoses, epidermo dysplasia verruciformis, oral leukoplakia, melanoma, and cutaneous T-cell lymphomas. In these conditions, treatment with retinoids has not a therapeutic value, but may prevent the formation of new lesions as long as therapy is prescribed. Lippman et al. reported a complete or partial response to oral retinoids in $51 \%$ of patients affected by basal cell carcinoma, in $71 \%$ of patients presenting advanced squamous cell carcinoma [34]. Moreover, daily administration of etretinate 0.5 to $1 \mathrm{mg}$ $\mathrm{kg}^{-1}$ was proven effective in inducing complete regression of actinic keratoses [35]. Other studies showed that high-dose of oral isotretinoin (2 $\mathrm{mg} / \mathrm{kg} /$ day) decreased the yearly incidence of new basal and squamous cell carcinomas in 5 patients affected by xeroderma pigmentosum $[36,37]$.

Vitamin A plays a relevant role in facilitating wound healing, in particular it seems to rescue the impairment of the regenerating process caused by corticosteroids and other medications. Vitamin A may enhance wound healing by participating in glycoprotein and glycolipid synthesis, prostaglandin production, and cell membrane metabolism. It also appears to influence 
dermal growth by inhibiting collagenase. Conversely, vitamin A deficiency delays collagen synthesis and reepithelialization, decreases collagen stability, and increases susceptibility to infection $[20,38]$.

\section{Treatment of Psoriasis with Retinoids}

Topical and systemic vitamin A derivatives are highly effective in the treatment of psoriasis. Retinoids may inhibit the growth of proliferating keratinocytes and induce their terminal differentiation. The effectiveness of topical and systemic vitamin A analogues in psoriasis is well known: tazarotene $0.05 \%$ and $0.1 \%$ gels are effective in treating mild to moderate plaque psoriasis not exceeding $20 \%$ of total body surface area. Side effects include mild to moderate local irritation, pruritus, burning, or erythema. Acitretin at the dosage of 0.5 to $1.0 \mathrm{mg} / \mathrm{kg} / \mathrm{day}$ is considered the retinoid of choice in the treatment of pustular psoriasis, but the potential occurrence of adverse events such as hair loss, hypertriglyceridemia, hyperostosis, tissue calcification, xerosis, and teratogenicity, represent a significant issue to its use [39-44].

\section{VITAMIN B COMPLEX}

Vitamin B complex consists of eight water-soluble vitamins found in meat, dairy products, vegetables, fish, brewer's yeast (beer), and cereals. Main functions performed by this group of vitamins act on cell proliferation, promoting muscle tone, immune balance and maintaining a normal functionality of the nervous system $[45,46]$.

\section{Vitamin B1 (thiamin)}

Thiamine (aneurine) is a coenzyme involved in oxidative decarboxylation reactions and transketolation (Table 2).

Its deficiency leads to "beriberi" disease and it is due to chronic alcoholism, hypovitaminosis, malabsorption, thyrotoxicosis, and rarely it might be correlated to thiaminase activity, an enzymecatabolizing thiamine, especially found in raw fish (Table 1). This condition is characterized by severe neurological and cardiovascular diseases associated to skin manifestations. An increased rate of seborrheic dermatitis-like lesions was observed in patients affected by beriberi, whereas aenterohepatica acrodermatitis-like (pluriorificial) dermatitis was correlated with amblyopia and peripheral neuritis [47].
Deficiencies of thiamine can also compromise and reduce the normal wound healing process, resulting in a decreased breaking resistance [48].

\section{Vitamin B2 (riboflavin)}

Riboflavinis are mainly found as coenzymes flavin mononucleotide (FMN) and flavin adenine dinucleotide (FAD), while a small percentage is represented as free riboflavin. Riboflavin plays a pivotal role as cofactor in metabolic and oxidation-reduction reactions. Furthermore, it is also involved in vitamin B6 metabolism.

Milk, dairy products, fatty fish, eggs, green leafy vegetables, whole grains, and enriched breads are rich in riboflavin. The recommended daily intake ranges from 0.3 to $1.6 \mathrm{mg}$, depending on age and gender [49].

Patients with riboflavin deficiency (also known as ariboflavinosis) show a deep erythema, mucositis, and in some cases, epidermal necrolysis. The severity of these symptoms are correlated to the deficiency degree.

Chronic manifestations of riboflavin deficiency are described as oro-oculo-genital syndrome. It begins with small papules in the corner of the mouth, which increase in size and bleed (angular stomatitis). Cheilitis, erythema, xerosis, and cracking of the lips are frequently associated. Glossitis with hyperplasia of the lingual papillae may occur and become chronic, resulting in a smooth and magenta-colored tongue. A facial seborrheic dermatitis-like eruption form might also appear.

Scrotal dermatitis, ocular manifestations includephotophobia, conjunctivitis, and corneal vascularization represent other manifestations of ariboflavinosis, though less frequent [50].

The skin symptoms of hypovitaminosis B2 are similar to the symptoms correlated to B6 deficiency, but also to deficiency of niacin, essential fatty acids, and in cases of acrodermatitis enterohepatica (zinc-deficiency syndrome), and glucagonoma [47].

\section{Vitamin B3 (niacin)}

Niacin (nicotinic acid o vitamin B3) and its converted form, nicotinamide adenine dinucleotide (NAD) and nicotinamide adeninedinucleotide phosphate (NADPH), are important cofactors in a variety of oxido-reductases reactions. 
Meat, poultry, nuts, eggs, fish, dry beans, coffee and fortified grains are dietary sources of NAD and $\mathrm{NADPH}$. They are hydrolyzed to nicotinamide in the intestinal lume, where intestinal bacteria convert it into nicotinic acid and both can be so absorbed and pass into the bloodstream. They are then transported to the liver, kidneys, and again to the intestine, where they are converted back to NAD and NADPH. The recommended daily intake is 13 to $20 \mathrm{mg}$, depending on age and gender. Moreover, about half of niacin present in our organism is produced by the conversion from tryptophan, but this process requires the involvement of vitamins B2 and B6 [1,51].

The classical manifestation of niacin deficiency is pellagra, classically defined by a tetrad: dermatitis, dementia,diarrhea, and death (Table 1).

The cutaneous manifestations can be divided into four categories: dermatitis on sun-exposed areas; perianal and genital dermatitis, lichenification and hyperpigmentation on osseous prominences, and a dermatitis mimicking seborrheic eczema $[52,53]$.

The dermatitis is bilateral, symmetrical, and characterized, at the beginning, by a hitching, erythematosus and edematous eruption after sun exposure. By time, the eruption turns into vesiclesbullous lesions, and eventually, hyperpigmented and keratotic plaques. Cheilitis, glossitis, angular stomatitis, and oralor perirectal ulcers may be observed.

Skin symptoms are not correlated with the severity of the systemic involvement. Neurologic symptoms include headache, irritability, anxiety, hallucinations, photophobia, depression, insomnia, and impaired memory. Nausea, vomiting, abdominal pain, and diarrhea represent the most common gastrointestinal manifestations. Death occurs within 4 to 5 years in absence of treatment $[53,54]$.

The clinical symptoms of pellagra are not only correlated by niacin deficiency. As previously mentioned, vitamin B3 in our body depends from both dietary sources or correlated to the metabolism of tryptophan that is controlled and regulated by vitamins B1, B2, B6 and amino acids. Hence, the lack of these nutrients can result in a deficiency of niacin. In fact symptoms similar to pellagra also occurs either in case of vitamin B2, B6, and zinc deficiency, or because of the lack of essential fatty acids, and in presence of glucagonoma [53,55].

\section{Vitamin B6}

The vitamin B6 group is represented by pyridoxine, pyridoxal, and pyridoxamine, and theirphosphates forms. Pyridoxal phosphate is a coenzyme for multiple critical enzymes. The phosphorylated form of vitamin B6 needs to be hydrolyzed by intestinal phosphatases before intestinal absorption. It is phosphorylated again in the liver and released into the blood circulation in its active forms. The recommended daily intake ranges from 0.1 to $2 \mathrm{mg}$, depending on age and gender $[1,55]$.

Vitamin B6 deficiency is uncommon but may occur in case of inadequate dietary intake, chronic alcoholism, uremia, malabsorption, hepatic cirrhosis and it might caused by therapy with isoniazid, hydralazine, cycloserine, penicillamine, and oral contraceptives. All these medications inactivate pyridoxal-5-phosphate or accelerate its excretion.

The most common skin manifestation is a seborrheic eruption localized in the facial, neck, and shoulder areas, in the perianal region, and in the perineum. Glossitis (characterized by flattening of the filiform papillae, redness, burning, and swelling of the tongue), stomatitis with ulcerations, cheilitis, aphtha, conjunctivitis, and intertrigo may occur. A pellagra-like dermatitis, somnolence, confusion, peripheral neuropathy, hypochromic and microcytic anemia have often been reported $[47,55,56]$

\section{Vitamin B12}

Cobalamin (vitamin B12) is another important coenzyme found in animal products, particularly liver, eggs, milk, and beef are rich sources of cobalamin [57].

After ingestion, gastric acid releases vitamin B12 and so it can bind to the intrinsic factor. Specific receptors take up the vitamin B12-intrinsic factor complex in the terminal ileum. After the dissociation from the intrinsic factor, Vitamin B12 reaches the portal circulation to be delivered to target tissues [58].

Causes of vitamin B12 deficiency are: decreased gastric acid secretion, decreased intrinsic factor production, microbial competition in the gut, or impaired absorption. The primary manifestation of a vitamin B12 deficiency is the megaloblastic anemia and the presence of hypersegmented neutrophils [59].

Cutaneous hyperpigmentation (diffuse or localized) might occur and it commonly affects hands, nails, face, 
palmar creases, flexural regions, and pressure points [60].

Mucocutaneous manifestations include angular cheilitis, Hunter glossitis (characterized by atrophic, red, and painful tongue, with atrophy of the filiform papillae), localized or diffuse hair depigmentation, and mucocutaneous hyperpigmentation [61].

Symptoms include generalized weakness with paresthesia that progress to ataxia and symmetric loss of vibration perception and proprioception, which is more severe at lower extremities [62]. Other neurologic findings include apathy, somnolence, irritability, memoryloss, dementia, and psychosis [63].

By highlighting the immunomodulatory effects of vitamin B12 on T lymphocytes and cytokines, studies propone that vitamin B12 may be implicated in the pathogensis of psoriasis on account of its role in nucleic acid synthesis [64,65].

Studies have recently started to examine the potential use of vitamin B12 in psoriasis therapy for patients demonstrating low levels of this vitamin in psoriatic plaques, and thus far, efficacy has been established with both intramuscular and systemic vitamin B12 [66-68]. Additional research has also verified the benefit of topical vitamin B12. A randomized, prospective clinical trial evaluated the effects of topical calcipotriol cream vs vitamin B12 cream $(700 \mathrm{mg} / \mathrm{kg}$ methyl glycoside stearate) containing avocado oil (containing $82.9 \mathrm{mg} / \mathrm{kg}$ vitamin $\mathrm{E}, \boldsymbol{\alpha}$-tocopherol) applied twice daily for 12 weeks in thirteen patients with chronic plaque psoriasis. Use of both creams resulted in a statistically significant improvement in the PASI score. Though the beneficial effects in the vitamin B12 group were slower to develop, by week 12, the two groups expressed no notable differences in PASI scores [69].

\section{Vitamin C}

Vitamin C (L-ascorbicacid) is a water-soluble molecule with a multitude of roles. Primarily, it acts as an essential cofactor for enzymes involved in carnitine synthesis and in collagen formation. Because of the role it plays in balancing calcium metabolism, it consequently aids osteoblast formation of bone and osteodentin formation of teeth. Vitamin C, furthermore, is involved in the synthesis of catecholamines (e.g., dopamine and norepinephrine), and increases dietary iron absorption by reducing iron from its ferric to ferrous state [70]. As an antioxidant, it boosts cellular protection against UV-induced DNA damage and lipid peroxidation, in addition to increase the immune response [71-75].

Finally, vitamin $\mathrm{C}$ participates in the formation of stratum corneum barrier lipids as it normalizes epidermal lipid formation, including glucosphingolipids and ceramides [76].

Humans are unable to synthesize vitamin $\mathrm{C}$ and are totally dependent on diet. Vitamin $\mathrm{C}$ can be found in strawberries, green leafy vegetables, citrus fruits, berries, cantaloupes, tomatoes, potatoes and herbs [70].

Vitamin $\mathrm{C}$ is absorbed in the first two-thirds of the small intestine, it is not stored but renally reabsorbed. The recommended daily intake depends on age and gender, ranging from 40 to $120 \mathrm{mg}$. [58].

Vitamin C deficiency is associated with collagen defects, defective fibroblast responses and white cell production, abnormal scar tissue formation, impaired use of oxygen free radicals for killing bacteria, and $\mathrm{y}$ globulin production [77-81].

Scurvy is the classical manifestation of vitamin C deficiency (Table 1). Fresh citrus fruits were identified in the past as a treatment and prevention of ascorbic acid deficiency [82]. Sailors were frequently affected of scurvy, which represented the most likely cause of death of a sailor's voyage [83].

Scurvy is characterized by fatigue, malaise, and lethargy. Skin signs are represented by enlarged, hyperkeratotic hair follicles on the posterolateral parts of the arms, on the buttocks and legs, associated with an abnormal hair development, coiled (corkscrew) hair, "swanneck" hair, woody edema of the legs [84]. Oral manifestations are edematous, friable, erythematous and bleeding gingiva, with prominent red, smooth, swollen masses in the interdentate papillae; teeth are prone to infection $[85,86]$. Xerostomia, keratoconjunctivitis sicca, and salivary glands hyperplasia might occur, mimicking Sjögren syndrome [87].

Other symptoms reflecting the fragility of blood vessel walls are conjunctival and intraocular hemorrhage, gastrointestinal bleeding, anemia, folate deficiency, and iron deficiency [88-89].

Despite the promising findings from in vitro and experimental studies that suggest a protective role of 
vitamin C in NMSC risk, though data from the literature are contradictory [90-98].

Role of vitamin C in wound healing process is also controversial because evidence does not unanimously show its positive effect in promoting healing processes [79-81,99-102].

Ascorbic acid is commonly used in a number of cosmetic products claiming to protect the skin from environmental insults and photoaging [93, 103-105].

\section{Vitamin D}

Vitamin $D$ is a fat-soluble vitamin that can be obtained through dietary sources as ergocalciferol (vitamin D2) or endogenous synthesis as cholecalciferol (vitamin D3). It is found naturally in fish and fish oils, having the greatest amount of vitamin $D$ available in raw natural products, but also liver, egg yolk, cheese, and mushrooms may represent alternative sources for vitamin D [106]. Clearly, it could be also found as an additive in fortified milk and cereal, or as a dietary supplement. The daily recommended intake is $200 \mathrm{IU}$ from birth to 50 years, $400 \mathrm{IU}$ from 51 to 70 years, and $600 \mathrm{IU}$ for 71 years and older [107].

After intestinal absorption, ergocalciferol is converted, by vitamin D 25-hydroxylase, into 25hydroxyvitamin $D$ (calcidiol) within the liver, and released into the circulation. Through the blood vessel system, it reaches the kidney, where it is transformed to its active form, 1,25-dihydroxyvitamin $D$ (calcitriol) [108].

However, the eighty percent of the human vitamin D synthesis begins within the skin, where the process of photoisomerization of 7-dehydrocholesterol to previtamin D3 occurs. Epidermal keratinocytes and dermal fibroblasts require ultraviolet $B$ light in the range of 290- to 315-nm for the production of Vitamin D. Previtamin D3 is transported to the liver and kidney and is converted to 1,25-dihydroxyvitamin $D$ by the same pool enzymes implicated into the process for dietary vitamin D [109-110].

Vitamin D is essential for regulation of calcium and phosphorous metabolisms, in fact, it activates bone osteoclasts in mobilizing calcium and phosphorus, and stimulates enterocyte calcium channel synthesis in order to enhance calcium absorption [108,111,112]. Together with the relevant role of in calcium homeostasis and bone metabolism, vitamin D seems to be involved in the physiologic metabolism of other tissues and organs including the adipose tissue, kidney, endocrine and cardiovascular systems. There are conflicting data about the correlation between low levels or deficiency of vitamin D and the onset of type II diabetes, insulin resistance, obesity, metabolic syndrome, hypertension, dyslipidemia, and cardiovascular diseases. [113-121]

Albeit a statistical correlation has been found, controversial evidence about an eventual causality of vitamin $D$ deficiency in inducing obesity has been reported: in fact, some authors suggested low levels of $25(\mathrm{OH}) \mathrm{D}$ as predisposing factor for obesity or insulin resistance, but in obese patients low vit. D levels can be likely attributed mainly to its sequestration by adiposity, poor vitamin intake, limited sun exposure, and reduced bioavailability. [122-124]

Skin cells, including keratinocytes, Langerhans cells, melanocytes, fibroblasts, dermal dendritic cells, B and $T$ cells, and endothelial cells, express vitamin $D$ nuclear receptor. The activation of this receptor, when it is bound to vitamin D and its analogs, leads to: (i) the inhibition of the keratinocyte proliferation; (ii) promotion of both in vitro and in vivo keratinocyte differentiation; and (iii) regulation of the cutaneous immune system, antiproliferative and proapoptotic effects (Table 2) [125127].

Overall these multiple effects contribute to the therapeutic success of this class of molecules in the treatment of psoriasis [128-132].

The effect of oral 1,25-(OH)2-D3 in the treatment of psoriasis was proven effective though it might be associated with the occurrence of adverse events such as hypercalcemia, hypercalciuria, nephrocalcinosis, nephrolithiasis, and reduction in bone mineral density. Initial clinical experience with oral vitamin D3 showed a potential benefit for the treatment of psoriasis [133134]. A small prospective study was conducted on 17 patients with moderate to severe psoriasis treated with either oral or topical 1,25-(OH)2-D3, starting with a dose of $0.25 \mu \mathrm{g}$ once or twice daily. Thereafter, dosing was increased as long as urinary calcium levels remained within the normal range. During the study, it was observed that a single dose at bedtime, rather than twice daily, helped to minimize the hypercalciuria. Of the 14 patients, ten showed a "significant clearing," whereas 4 patients had no benefit or only mild clinical response [135].

A 6-month, pilot study testing daily oral 1,25- $(\mathrm{OH}) 2-$ D3 administration in patients affected psoriatic arthritis 
showed at least moderate improvement for 7 of 10 patients. Four of nine patients evaluated for their skin lesions experienced a marked improvement, whereas a worsening of the psoriatic plaques was observed in two patients [136]. Similarly, another trial showed that oral 1,25-(OH)2-D3 at 0.5 to $2 \mu \mathrm{g} /$ day prescribed for 6 months, induced at least a moderate response in skin lesions in two of eight enrolled patients [137].

Because of its immunomodulatory effect, vitamin D has also been used to treat inflammatory diseases. The therapeutic efficacy of oral calcitriol and calcipotriene in the treatment of morphea has been well reported $[138,139]$. Based on this result, the efficacy of vitamin $D$ has been proved in the treatment of lichen sclerosus. A specific mechanism of action has not fully understood, but a number of case reports documented the effectiveness of topical calcipotriene on extragenital lichen sclerosus [140-143].

Several studies investigated the use of vitamin $D$ and its analogues as chemoprevention for melanoma and metastasis of malignant tumors. The association between high levels of 25-hydroxyvitamin D3 and low melanoma lesion thickness at the time of diagnosis was observed in two different studies $[144,145]$.

A large cohort of 70000 patients affected by melanoma, on the contrary, did not demonstrate the existence of a relationship between melanoma incidence and vitamin D intake [146]. This result could be probably explained by varying susceptibilities to melanoma based on various vitamin $D$ receptor gene polymorphisms [145]. Nevertheless, vitamin D may still be important in melanoma chemoprevention in some individuals.

In vitro studies suggested an association between vitamin D and non-melanoma skin cancers (NMSC), because of the vitamin $D$ interaction with intranuclear vitamin $D$ receptors (VDRs), expressed in keratinocytes [147-150].

Unfortunately, clinical data concerning the potential benefit of vitamin D on NMSC are lacking. The effect of topical calcipotriol (6-week application) on actinic keratoses (AKs) resulted poor [151]. On the contrary showed that 12-week application of topical calcipotriol significantly ameliorated AKs, compared with application of placebo [152]. Other studies failed to show an association between vitamin $D$ and BCCs [153-155].

\section{Vitamin E}

Vitamin $E$ includes eight naturally occurring forms of a fat-soluble antioxidant $(\alpha-, \beta-, \gamma-$, and $\delta$-tocopherols and tocotrienols) that are present in vegetables, oils, seeds, corn, soy, whole wheat flour, margarine, nuts, some meats, asparagus, avocado, eggs, seeds, nuts, spinach, and some dairy products $[156,157]$

Vitamin E, as an intracellular antioxidant, protects cell membrane from a wide spectrum of free radicals including singletoxygen, superoxide, and hydroxyl radicals, and it is fundamental as a chain-breaking antioxidant during lipid peroxidation in membranes [156,158-160].

In relation to its anti-inflammatory action, vitamin $\mathrm{E}$ has been used for various dermatological conditions: as skin protector for acute and chronic dermatitis, sunburn, and UV light-induced long-term damages (Table 2) [161-171]. It also seems to be effective in (i) reducing sebum production in seborrheic skin [172], (ii) promoting hair growth possibly increasing microcirculation [173], (iii) decreasing pruritus [174,175], (iv) accelerating wound healing [176-179], and $(v)$ protecting from hypertrophic scar formation (Table 2) [180-183].

The effects of oral and topical vitamin $E$ on skin photoaging effects, skin cancer formation, sunburn prevention need to be defined [162-171, 184-190].

Interestingly, studies on elderly population indicate a lower incidence of infectious disease and cancer in subjects maintaining high plasma tocopherol levels [191-194].

Several authors reported the satisfactory use of vitamin $E$ as co-adjuvant in various inflammatory conditions of the skin such as discoid lupus erythematosus and lichen sclerosus et atrophicus [195199].

The yellow nail syndrome, an uncommon condition associated with lymphatic obstruction and pleural effusions, could be treated with vitamin $E[200,201]$. The peculiar yellow coloration is due to the presence of the lipofuscin, derived from lipid oxidation [202]. Through its antioxidant effect, vitamin E may inhibit the pigment production [200].

\section{Vitamin $\mathrm{K}$}

Vitamin $\mathrm{K}$ belongs to a group of fat-soluble vitamins, occurring asphylloquinone (vitamin K1) in green leafy 
vegetables, liver, Brussels sprouts, lentils, plant oils, and soybeans. It is absorbed in the uppersmall intestine, where gastrointestinal bacteria synthesize approximately $50 \%$ of daily vitamin $\mathrm{K}$ (asmenaquinone, vitamin K2). Recommended daily intake of vitamin K ranges from 2 to $120 \mu \mathrm{g}$, similarly for age and gender [203].

Vitamin $\mathrm{K}$ is involved in bone metabolism and is essential for synthesis of several coagulation factors such as factor II, factor VII, factor IX, factor X, protein C, and protein S [203-206].

Vitamin $\mathrm{K}$ deficiency impairs coagulation cascade resulting in hemorrhagic events (i.e., cutaneous, gastrointestinal, genitourinary, and retroperitoneal bleeding), purpura, and ecchymosis [206-210] Furthermore, alteration of multiple biologic processes including wound repair, host defense against infection is common in vitamin $\mathrm{K}$ deficiency [211, 212]

\section{CONCLUSION}

The therapeutic approach in skin disorders has profoundly changed in the last few decades. Vitamins represent a relevant class of therapeutic agents and co-adjuvants in the management of cutaneous diseases. Due to their antioxidant effects, vitamins might constitute an important support to conventional drugs and to chronic inflammatory state, and their cosmetic effects might represent a useful tool for various disorders.

Vitamin A and vitamin D derivates that successfully act on specific pathological aspects of common inflammatory skin diseases such as acne and psoriasis represent two principal examples of the significant contribution of vitamins in skin therapy.

The role of vitamins in the management of skin disorders is often underestimated, and though further investigations are necessary to explore their potentiality, their use would propone a therapeutic alternative whose health benefits extend beyond the realm of skin disease.

\section{REFERENCES}

[1] Jen M, Yan AC. Syndrome associated with nutritional deficiency and excess. Clinics in Dermatology 2010; 28: 66985.

\section{http://dx.doi.org/10.1016/j.clindermatol.2010.03.029}

[2] Brun PJ, Yang KJ, Lee SA, Yuen JJ, Blaner WS. Retinoids: Potent regulators of metabolism. Biofactors 2013; 39(2): 15163.

http://dx.doi.org/10.1002/biof.1056
[3] Alvarez S, Bourguet W, Gronemeyer H, de Lera AR. Retinoic acid receptor modulators: a perspective on recent advances and promises. Expert Opin Ther Pat 2011; 21(1): 55-63. http://dx.doi.org/10.1517/13543776.2011.536531

[4] Maire Al, Alvarez S, Shankaranarayanan P, Lera AR, Bourguet W, Gronemeyer $H$. Retinoid receptors and therapeutic applications of RAR/RXR modulators. Curr Top Med Chem 2012; 12(6): 505-27. http://dx.doi.org/10.2174/156802612799436687

[5] Mihály J, Gericke J, Aydemir G, Weiss K, Carlsen H, Blomhoff $\mathrm{R}$, et al. Reduced retinoid signaling in the skin after systemic retinoid-X receptor ligand treatment in mice with potential relevance for skin disorders. Dermatology 2012; 225(4): 304-11 http://dx.doi.org/10.1159/000345496

[6] Steinemann T, Christiansen S. Vitamin A deficiency and xerophthalmia in an autistic child. Arch Ophthalmol 1998; 116: 392-3.

http://dx.doi.org/10.1001/archopht.116.3.392

[7] Sherwin JC, Reacher MH, Dean WH, Ngondi J. Epidemiology of vitamin A deficiency and xerophthalmia in at-risk populations. Trans R Soc Trop Med Hyg 2012; 106(4): 205-14.

http://dx.doi.org/10.1016/j.trstmh.2012.01.004

[8] Ragunatha S, Kumar VJ, Murugesh SB. A clinical study of 125 patients with phrynoderma. Indian J Dermatol 2011; 56(4): 389-92.

http://dx.doi.org/10.4103/0019-5154.84760

[9] Chia MW, Tay YK, Liu TT. Phrynoderma: a forgotten entity in a developed country. Singapore Med J 2008; 49(6): e160-2. http://www.ncbi.nlm.nih.gov/pubmed/18581010

[10] Heath ML, Sidbury L. Cutaneous manifestation of nutritional deficiency. Curr Opin Pediatr 2006; 18(4): 417-22. http://dx.doi.org/10.1097/01.mop.0000236392.87203.cc

[11] Maroon M, Allen DM, Esterly NB. Phrynoderma: a manifestation of vitamin A deficiency? The rest of the story. Pediatr Dermatol 2005; 22(1): 60-3. http://dx.doi.org/10.1111/j.1525-1470.2005.22113.x

[12] Goldberg JL, Lenzy Y. Nutrition and hair. Clin Dermatol 2010; 28: 412-9. http://dx.doi.org/10.1016/j.clindermatol.2010.03.038

[13] Fuchs J. Alcoholism, malnutrition, vitamin deficiencies, and the skin. Clin Dermatol 1999; 17: 457-61. http://dx.doi.org/10.1016/S0738-081X(99)00032-2

[14] Nicol NJ, Fenske NA. Photodamage: cause clinical manifestations, and prevention. Dermatol Nurs 1993; 5(4): 263-75; quiz 276-7.

[15] Fisher GJ, Datta SC, Talwar HS, Wang ZQ, Varani J, Kang $\mathrm{S}$, Voorhees JJ. Molecular basis of sun-induced premature skin aging and retinoid antagonism. Nature 1996; 379(6563): 335-9.

http://dx.doi.org/10.1038/379335a0

[16] Elson ML. Topical tretinoin in the treatment of striae distensae and in the promotion of wound healing: a review. $J$ Dermatol Treat 1994; 5(3): 163-5. http://dx.doi.org/10.3109/09546639409084563

[17] Kang S, Kim KJ, Griffiths CE, Wong TY, Talwar HS, Fisher GJ, et al. Topical tretinoin (retinoic acid) improves early stretch marks. Arch Dermatol 1996; 132 (5): 519-26. http://dx.doi.org/10.1001/archderm.1996.03890290053007

[18] Zheng P, Lavkar RM, Kligman AM. Anatomy of striae. $\mathrm{Br} J$ Dermatol 1985; 112(2): 185-93 http://dx.doi.org/10.1111/j.1365-2133.1985.tb00082.x

[19] Kligman AM, Pagnoni A, Stoudemayer T. Topical retinol improves cellulite. J Dermatol Treat 1999; 10(2): 119-25.

[20] Hunt TK. Vitamin A and wound healing. J Am Acad Dermatol 1986; 15: 817-21.

http://dx.doi.org/10.1016/S0190-9622(86)70238-7 
[21] Christiansen JV, Gadborg E, Ludvigsen K, Meier $\mathrm{CH}$, Norholm A, et al. Topical tretinoin, vitamin A acid (Airol) in acne vulgaris. A controlled clinical trial. Dermatologica 1974; 148(2): 82-9.

http://dx.doi.org/10.1159/000251602

[22] Layton AM, Stainforth JM, Cunliffe WJ. Ten years' experience of oral isotretinoin for the treatment of acne vulgaris. J Dermatol Treat 1993; 4: S2. http://dx.doi.org/10.3109/09546639309082157

[23] Leyden JJ, McGinley KJ, Foglia AN. Qualitative and quantitative changes in cutaneous bacteria associated with systemic isotretinoin therapy for acne conglobate. J Invest Dermatol 1986; 86: 390-3.

http://dx.doi.org/10.1111/1523-1747.ep12285658

[24] Strauss JS, Rapini RP, Shalita AR, Konecky E, Pochi PE, Comite $\mathrm{H}$, Exner $\mathrm{JH}$. Isotretinoin therapy for acne: results of a multicenter dose-response study. J Am Acad Dermatol 1984; 10 (3): 490-6.

http://dx.doi.org/10.1016/S0190-9622(84)80100-0

[25] Plewig G, Nikolowski J, Wolff $\mathrm{HH}$. Action of isotretinoin in acne rosacea and gram-negative folliculitis. J Am Acad Dermatol 1982; 6: 766-85.

http://dx.doi.org/10.1016/S0190-9622(82)70067-2

[26] Löwhagen GB, Michaëlsson G, Mobacken H, Pettersson U, Vahlquist A. Effects of etretinate (Ro 10-9359) on Darier's disease. Dermatologica 1982; 165(2): 123-30. http://dx.doi.org/10.1159/000249930

[27] Blanchet-Bardon C, Nazzaro V, Rognin C, Geiger JM, Puissant A. Acitretin in the treatment of severe disorders of keratinization: results of an open study. J Am Acad Dermatol 1991; 24: 982-6.

http://dx.doi.org/10.1016/0190-9622(91)70158-X

[28] Goldsmith LA, Weinrich AE, Shupack J. Pityriasis rubra pilaris response to 13-cis-retinoic acid (isotretinoin). J Am Acad Dermatol 1982; 6: 710-5. http://dx.doi.org/10.1016/S0190-9622(82)70061-1

[29] Borok $M$, Lowe NJ. Pityriasis rubra pilaris: further observations of systemic retinoid therapy. J Am Acad Dermatol 1990; 22: 792-5. http://dx.doi.org/10.1016/0190-9622(90)70110-4

[30] Cohen PR, Prystowsky JH. Pityriasis rubra pilaris: a review of diagnosis and treatment. J Am Acad Dermatol 1989; 20: 8017.

http://dx.doi.org/10.1016/S0190-9622(89)70093-1

[31] Fisher GJ, Wang ZQ, Datta SC, Varani J, Kang S, Voorhees JJ. Pathophysiology of premature skin aging induced by ultraviolet light. N Engl J Med 1997; 337: 1419-28. http://dx.doi.org/10.1056/NEJM199711133372003

[32] Kligman AM, Grove GL, Hirose R, Leyden JJ. Topical tretinoin for photoaged skin. J Am Acad Dermatol 1986; $15(4$ Pt 2): 836-59.

http://dx.doi.org/10.1016/S0190-9622(86)70242-9

[33] Weinstein GD, Nigra TP, Pochi PE, Savin RC, Allan A, et al. Topical tretinoin for treatment of photodamaged skin: a multicenter study. Arch Dermatol 1991; 27(5): 659-65. http://dx.doi.org/10.1001/archderm.1991.01680040067005

[34] Lippman SM, Shimm DS, Meyskens FL Jr. Nonsurgical treatments for skin cancer: retinoids and alpha-interferon. $J$ Dermatol Surg Oncol 1988; 14: 862-9.

[35] Alirezai M, Dupuy $P$, Amblard $P$, Kalis B, Souteyrand $P$, Frappaz A, Sendagorta E. Clinical evaluation of topical isotretinoin in the treatment of actinic keratoses. J Am Acad Dermatol 1994; 30: 447-51. http://dx.doi.org/10.1016/S0190-9622(94)70054-0

[36] Tangrea JA, Edwards BK, Taylor PR, Hartman AM, Peck GL, Salasche SJ, et al. Long-term therapy with low dose isotretinoin for prevention of basal cell carcinoma: a multicenter trial. J Natl Cancer Inst 1992; 84: 328-32. http://dx.doi.org/10.1093/jnci/84.5.328
[37] Kraemer KH, DiGiovanna JJ, Moshell AN, Tarone RE, Peck GL. Prevention of skin cancer in xeroderma pigmentosum with the use of oral isotretinoin. N Engl J Med 1988; 318: 1633-7.

http://dx.doi.org/10.1056/NEJM198806233182501

[38] Bailly C, Drèze $S$, Asselineau $D$, Nusgens B, Lapière CM, Darmon M. Retinoic acid inhibits the production of collagenase by human epidermal keratinocytes. J Invest Dermatol 1990; 94: 47-51. http://dx.doi.org/10.1111/1523-1747.ep12873342

[39] Robinson A, Van Voorhees AS, Hsu S, Korman NJ, Lebwhol MG, Bebo BF Jr, Kalb RE. Treatment of pustular psoriasis: from the Medical Board of the National Psoriasis Foundation. J Am Acad Dermatol 2012; 67(2): 279-88. http://dx.doi.org/10.1016/j.jaad.2011.01.032

[40] Arechalde A, Saurat HJ. Management of psoriasis: the position of retinoid drugs. BioDrugs 2000; 13(5): 327-33. http://dx.doi.org/10.2165/00063030-200013050-00003

[41] Orfanos CE. Treatment of psoriasis with retinoids: present status. Cutis 1999; 64(5): 347-53.

[42] Ling MR. Acitretin: optimal dosing strategies. J Am Acad Dermatol 1999; 41(3 pt 2): S13-7.

[43] Katz HI, Waalen J, Leach EE. Acitretin in psoriasis: an overview of adverse effects. J Am Acad Dermatol 1999; 41(3 pt 2): S7-S12.

[44] Gollnick HP. Oral retinoids-efficacy and toxicity in psoriasis. Br J Dermatol 1996; 135(Suppl 49): 6-17. http://dx.doi.org/10.1111/j.1365-2133.1996.tb15661.x

[45] Gisondi P, Fantuzzi F, Malerba M, Girolomoni G. Folic acid in general medicine and dermatology. J Dermatolog Treat 2007; 18(3): 138-46. http://dx.doi.org/10.1080/09546630701247930

[46] Lansdown ABG. Nutrition 2: a vital consideration in the management of wounds. Br J Nurs 2004; 13: 1199-10.

[47] Fuchs J. Alcoholism, malnutrition, vitamin deficiencies, and the skin. Clin Dermatol 1999; 17: 457-61. http://dx.doi.org/10.1016/S0738-081X(99)00032-2

[48] Alvarez OM, Gillbreath RI. Thiamine influence on collagen during granulation of skin wounds. J Surg Res 1982; 32: 24 31. http://dx.doi.org/10.1016/0022-4804(82)90180-9

[49] Abbas CA, Sibirny AA. Genetic control of biosynthesis and transport of riboflavin and flavin nucleotides and construction of robust biotechnological producers. Microbiol Mol Biol Rev 2011; 75(2): 321-60. http://dx.doi.org/10.1128/MMBR.00030-10

[50] Roe D. Riboflavin deficiency: mucocutaneous signs of acute and chronic deficiency. Semin Dermatol 1991; 10: 293-5.

[51] Lanska DJ. The discovery of niacin, biotin, and pantothenic Acid. Ann Nutr Metab 2012; 61(3): 246-53. http://dx.doi.org/10.1159/000343115

[52] Cakmak SKM, Gönül M, Aslan E, Gül U, Kiliç A, Heper AO. Halfand- half nail in a case of pellagra. Eur J Dermatol 2006; 16: 695-6.

[53] Hendricks WM. Pellagra and pellagra-like dermatoses: Etiology, differential diagnosis dermatopothology, and treatment. Semin Dermatol 1991; 10: 282-9.

[54] Brown TM. Pellagra: an old enemy of timeless importance. Psychosomatics 2010; 51(2): 93-7.

[55] Barthelemy H, Chouvet B, Cambazard F. Skin and mucosa manifestations in vitamin deficiency. J Am Acad Dermatol 1986; 15(6): 1263-74 http://dx.doi.org/10.1016/S0190-9622(86)70301-0

[56] Inubushi T, Takasawa T, Tuboi Y, Watanabe N, Aki K, Katunuma N. Changes of glucose metabolism and skincollagen neogenesis in vitamin B6 deficiency. Biofactors 2005; 23(2): 59-67.

http://dx.doi.org/10.1002/biof.5520230201 
[57] O'Leary F, Samman S. Vitamin B12 in health and disease. Nutrients 2010; 2(3): 299-316.

\section{http://dx.doi.org/10.3390/nu2030299}

[58] Quadros EV. Advances in the understanding of cobalamin assimilation and metabolism. Br J Haematol 2010; 148(2): 195-204.

http://dx.doi.org/10.1111/j.1365-2141.2009.07937.x

[59] Baumslag N, Metz J. Pigmentation in megaloblastic anaemia associated with pregnancy and lactation. Br Med J 1969; 2: 737-9.

http://dx.doi.org/10.1136/bmj.2.5659.737

[60] Noppakun N, Swasdikul D. Reversible hyperpigmentation of skin and nails with white hair due to vitamin B12 deficiency. Arch Dermatol 1986; 122: 896-9. http://dx.doi.org/10.1001/archderm.1986.01660200068018

[61] Mori K, Ando I, Kukita A. Generalized hyperpigmentation of the skin due to vitamin B12 deficiency. J Dermatol 2001; 28: 282-5.

[62] Crawford JR, Say D. Vitamin B12 deficiency presenting as acute ataxia. BMJ Case Rep 2013; 2013. doi:pii: bcr2013008840. http://casereports.bmj.com/content/2013/ bcr-2013-008840.long

[63] Lindenbaum J, Healton EB, Savage DG, Brust JC, Garrett TJ, Podell ER, et al. Neuropsychiatric disorders caused by cobalamin deficiency in the absence of anemia or macrocytosis. N Engl J Med 1988; 318(26): 1720-8. http://dx.doi.org/10.1056/NEJM198806303182604

[64] Sakane T, Takada S, Kotani H, Tsunematsu T. Effects of methyl-B12 on the in vitro immune functions of human $\mathrm{T}$ lymphocytes. J Clin Immunol 1982; 2: 101-9. http://dx.doi.org/10.1007/BF00916893

[65] Yamashiki M, Nishimura A, Koska Y. Effects of methylcobalamin (vitamin B12) on in vitro cytokine production of peripheral blood mononuclear cells. J Clin Lab Immunol 1992; 37: 173-82.

[66] Brazzelli V, Grasso V, Fornara L, Moggio E, Gamba G, Villani S, Borroni G. Homocysteine, vitamin B12 and folic acid levels in psoriatic patients and correlation with disease severity. Int J Immunopathol Pharmacol 2010; 23(3): 911-6.

[67] Rimbaud P, Ravoire J, Rioux J. Treatment of psoriasis by vitamine B12 with 1,000 gammas. Bull Soc Fr Dermatol Syphiligr 1955; 5: 509-10.

[68] Miura T, Torinuki W, Makino Y. Treatment of pustulosis palmaris et plantaris with large doses of vitamin B12. J Dermatol 1976; 3(4): 155-8.

[69] Stücker M, Memmel U, Hoffmann M, Hartung J, Altmeyer P. Vitamin B12 cream containing avocado oil in the therapy of plaque psoriasis. Dermatology 2001; 203: 141-7. http://dx.doi.org/10.1159/000051729

[70] Levine M. New concepts in the biology and biochemistry of ascorbic acid. New Engl J Med 1986; 314: 892-902. http://dx.doi.org/10.1056/NEJM198604033141407

[71] Wefers $H$, Sies $H$. The protection by ascorbate and glutathione against microsomal lipid peroxidation is dependent on Vitamin E. Eur J Biochem 1988; 174: 353-7. http://dx.doi.org/10.1111/j.1432-1033.1988.tb14105.x

[72] Scarpa M, Stevenato R, Viglino Rigo A. Superoxide ionas active intermediate in the autoxidation of ascorbate by molecular oxygen: effect of superoxide dismutase. J Biol Chem 1983; 258: 6695-7.

[73] Cabelli DE, Bielski BHJ. Kinetics and mechanism for the oxidation of ascorbic acid/ascorbate by $\mathrm{HO} / \mathrm{O} 2$ radicals: a pulse radiolysis and stopped flow photolysis study. J Phys Chem 1983; 87: 1805-12 http://dx.doi.org/10.1021/j100233a031

[74] Chou PT, Khan AU. L-ascorbic acid quenching of singlet delta molecular oxygen in aqueous media: generalized antioxidant property of vitamin C. Biochem Biophys Res Commun 1983; 115: 932-7. http://dx.doi.org/10.1016/S0006-291X(83)80024-2

[75] McCay PB. Vitamin E: interactions with free radicals and ascorbate. Annu Rev Nutr 1985; 5: 323-40.

\section{http://dx.doi.org/10.1146/annurev.nu.05.070185.001543}

[76] Ponec M, Weerheim A, Kempenaar J, Mulder A, Gooris GS Bouwstra J, et al. The formation of competent barrier lipids in reconstructed human epidermis requires the presence of vitamin C. J Invest Dermatol 1997; 109(3): 348-55. http://dx.doi.org/10.1111/1523-1747.ep12336024

[77] Phillips CL, Combs SB, Pinnell SR. Effects of ascorbic acid on proliferation and collagen synthesis in relation to the donor age of human dermal fibroblasts. $J$ Invest Dermatol 1994; 103: 228-32. http://dx.doi.org/10.1111/1523-1747.ep12393187

[78] Murad S, Grove D, Lindberg KA, et al. Regulation of collagen synthesis by ascorbic acid. Proc Natl Acad Sci USA 1981; 78(5): 2879-82.

http://dx.doi.org/10.1073/pnas.78.5.2879

[79] Lansdown ABG. Nutrition 2: a vital consideration in the management of wounds. Br J Nurs 2004; 13: 1199-10.

[80] Levenson SM, Demetriou AA. Metabolic factors. In: Cohen IK, Diegelmann R, Lindblad WJ, Eds. Wound healing: biochemical and clinical aspects. Philadelphia: Saunders; 1992; pp. 248-73.

[81] Bourne $\mathrm{GH}$. Effect of vitamin C deficiency on experimental wounds: tensile strength and histology. Lancet 1944; 1: 68892.

http://dx.doi.org/10.1016/S0140-6736(00)74919-1

[82] Martí N, Mena P, Cánovas JA, Micol V, Saura D. Vitamin C and the role of citrus juices as functional food. Nat Prod Commun 2009; 4(5): 677-700.

[83] Baron JH. Sailors' scurvy before and after James Lind--a reassessment. Nutr Rev 2009; 67(6): 315-32.

\section{http://dx.doi.org/10.1111/j.1753-4887.2009.00205.x}

[84] Woodier N, Koytzoumis V. 'Scurvy': presentation and skin manifestations of a not so uncommon condition. Emerg Med J 2012; 29(2): 103

http://dx.doi.org/10.1136/emermed-2011-200417

[85] Firth N, Marvan E. Oral lesions in scurvy. Aust Dent J 2001 46(4): 298-300. http://dx.doi.org/10.1111/j.1834-7819.2001.tb00294.x

[86] Touyz LZ. Oral scurvy and periodontal disease. J Can Dent Assoc 1997; 63(11): 837-45.

[87] Hood J, Burns CA, Hodges RE. Sjögren's syndrome in scurvy. N Engl J Med 1970; 282(20): 1120-4. http://dx.doi.org/10.1056/NEJM197005142822003

[88] Hood J, Hodges RE. Ocular lesions in scurvy. Am J Clin Nutr 1969; 22(5): 559-67. http://ajcn.nutrition.org/content/22/5/ 559.long

[89] Fain O. Vitamin C deficiency. Rev Med Interne 2004; 25(12): 872-80.

http://dx.doi.org/10.1016/j.revmed.2004.03.009

[90] Wei Q, Matanoski GM, Farmer ER, Strickland P, Grossman L. Vitamin supplementation and reduced risk of basal cell carcinoma. J Clin Epidemiol 1994; 47: 829-36. http://dx.doi.org/10.1016/0895-4356(94)90185-6

[91] Miyai E, Yanagida M, Akiyama J, Yamamoto I. Ascorbic acid 2-Oalpha-glucoside-induced redox modulation in human keratinocyte cell line, SCC: mechanisms of photoprotective effect against ultraviolet light B. Biol Pharm Bull 1997; 20: 632-6.

http://dx.doi.org/10.1248/bpb.20.632

[92] Bialy TL, Rothe MJ, Grant-Kels JM. Dietary factors in the prevention and treatment of nonmelanoma skin cancer and melanoma. Dermatol Surg 2002; 28(12): 1143-52. http://dx.doi.org/10.1046/j.1524-4725.2002.02114.x 
[93] Moison RM, Beijersbergen van Henegouwen GM. Topical antioxidant vitamins $\mathrm{C}$ and $\mathrm{E}$ prevent UVB-radiation-induced peroxidation of eicosapentaenoic acid in pig skin. Radiat Res 2002; 157: 402-9.

http://dx.doi.org/10.1667/0033-

7587(2002)157[0402:TAVCAE]2.0.CO;2

[94] Lupulescu A, Vitamin C inhibits DNA. RNA and protein synthesis in epithelial neoplastic cells. Int $\mathrm{J}$ Vitam Nutr Res 1991; 61: 125-9.

[95] Pauling L, Willoughby R, Reynolds R, Blaisdell BE, Lawson $\mathrm{S}$. Incidence of squamous cell carcinoma in hairless mice irradiated with ultraviolet light in relation to intake of ascorbic acid (vitamin C) and of D, L-alpha-tocopheryl acetate (vitamin E). Int J Vitam Nutr Res Suppl 1982; 23: 53-82.

[96] van Dam RM, Huang Z, Giovannucci E, Rimm EB, Hunter DJ, Colditz GA, et al. Diet and basal cell carcinoma of the skin in a prospective cohort of men. Am J Clin Nutr 2000; 71: 135-41. http://ajcn.nutrition.org/content/71/1/135.long

[97] Fung TT, Spiegelman D, Egan KM, Giovannucci E, Hunter DJ, Willett WC. Vitamin and carotenoid intake and risk of squamous cell carcinoma of the skin. Int J Cancer 2003; 103: $110-5$. http://dx.doi.org/10.1002/ijc.10798

[98] Heinen MM, Hughes MC, Ibiebele TI, Marks GC, Green AC, van der Pols JC. Intake of antioxidant nutrients and the risk of skin cancer. Eur J Cancer 2007; 43: 2707-16.

http://dx.doi.org/10.1016/j.ejca.2007.09.005

[99] Phillips C, Pinnell SR. Effects of ascorbic acid on proliferation and collagen synthesis in relation to the donor age of human dermal fibroblasts. Soc Invest Dermatol 1994; 103: 228-32. http://dx.doi.org/10.1111/1523-1747.ep12393187

[100] Finglas PM, Bailey A, Walker A, Loughridge JM, Wright AJ, Southon S. Vitamin C intake and plasma ascorbic acid concentration in adolescents. Br J Nutr 1993; 69: 563-76. http://dx.doi.org/10.1079/BJN19930056

[101] Fenske NA, Lober CW. Structural and functional changes of normal aging skin. J Am Acad Dermatol 1986; 15: 571-85. http://dx.doi.org/10.1016/S0190-9622(86)70208-9

[102] Leibovitz BE, Siegel BV. Aspects of free radical reactions in biological systems: aging. J Gerontol 1980; 35: 45-56. http://dx.doi.org/10.1093/geronj/35.1.45

[103] Darr D, Combs S, Dunston S, Manning T, Pinnell S. Topical vitamin $C$ protects porcine skin from ultraviolet radiationinduced damage. Br J Dermatol 1992; 127: 247-53. http://dx.doi.org/10.1111/j.1365-2133.1992.tb00122.x

[104] Murray J, Darr D, Reich J, Pinnell S. Topical vitamin C treatment reduces ultraviolet $B$ radiation-induced erythema in human skin. J Invest Dermatol 1991; 96: 587.

[105] Kameyama K, Sakai C, Kondoh S, Yonemoto K, Nishiyama $\mathrm{S}$, Tagawa $\mathrm{M}$, et al. Inhibitory effects of magnesium Lascorbyl-2-phosphate on melanogenesis in vitro and in vivo. J Am Acad Dermatol 1996; 34: 29-33. http://dx.doi.org/10.1016/S0190-9622(96)90830-0

[106] Lu Z, Chen TC, Zhang A, Persons KS, Kohn N, Berkowitz R, et al. An evaluation of the vitamin D3 content in fish. J Steroid Biochem Mol Biol 2007; 103: 642-4. http://dx.doi.org/10.1016/j.jsbmb.2006.12.010

[107] Dietary reference intakes. National Academy of Sciences. Washington, DC: National Academy Press 1997. http://www.nap.edu/openbook.php?record_id $=13050$

[108] Cline J. Calcium and vitamin d metabolism, deficiency, and excess. Top Companion Anim Med 2012; 27(4): 159-64. http://dx.doi.org/10.1053/j.tcam.2012.09.004

[109] Ponchon G, Kennan AL, DeLuca HF. "Activation" of vitamin $\mathrm{D}$ by the liver. J Clin Invest 1969; 48: 2032-7. http://dx.doi.org/10.1172/JCl106168
[110] Fraser DR, Kodicek E. Unique biosynthesis by kidney of a biological active vitamin D metabolite. Nature 1970; 228(5273): 764-6. http://dx.doi.org/10.1038/228764a0

[111] Holick MF. Optimal vitamin D status for the prevention and treatment of osteoporosis. Drugs Aging 2007; 24: 1017-29. http://dx.doi.org/10.2165/00002512-200724120-00005

[112] Cashman KD. Calcium and vitamin D. Novartis Food Symp 2007; 282: 123-38.

[113] Guasch A, Bulló M, Rabassa A, Bonada A, Del Castillo D, Sabench $F$, et al. Plasma vitamin $D$ and parathormone are associated with obesity and atherogenic dyslipidemia: a cross-sectional study. Cardiovasc Diabetol 2012; 11: 149. http://dx.doi.org/10.1186/1475-2840-11-149

[114] Pittas AG, Sun Q, Manson JE, Dawson-Hughes B, Hu FB. Plasma 25-hydroxyvitamin $D$ concentration and risk of incident type 2 diabetes in women. Diabetes Care 2010; 33: 2021-23. http://dx.doi.org/10.2337/dc10-0790

[115] Zhao G, Ford ES, Li C. Associations of serum concentrations of 25-hydroxyvitamin $\mathrm{D}$ and parathyroid hormone with surrogate markers of insulin resistance among U.S. adults without physician-diagnosed diabetes: NHANES, 2003-2006. Diabetes Care 2010; 33(2): 344-47. http://dx.doi.org/10.2337/dc09-0924

[116] Gagnon C, Lu ZX, Magliano DJ, Dunstan DW, Shaw JE, Zimmet PZ, et al. Serum 25-hydroxyvitamin D, calcium intake, and risk of type 2 diabetes after 5 years: results from a national, population-based prospective study (the Australian diabetes, obesity and lifestyle study). Diabetes Care 2011; 34(5): 1133-38. http://dx.doi.org/10.2337/dc10-2167

[117] Bhandari SK, Pashayan S, Liu IL, Rasgon SA, Kujubu DA, Tom TY, et al. 25-hydroxyvitamin D levels and hypertension rates. J Clin Hypertens (Greenwich) 2011; 13(3): 170-77. http://dx.doi.org/10.1111/j.1751-7176.2010.00408.x

[118] Karhapaa P, Pihlajamaki J, Porsti I, Kastarinen M, Mustonen $\mathrm{J}$, Niemela $\mathrm{O}$, et al. Diverse associations of 25hydroxyvitamin $\mathrm{D}$ and 1,25-dihydroxy-vitamin $\mathrm{D}$ with dyslipidaemias. J Intern Med 2010; 268(6): 604-10. http://dx.doi.org/10.1111/j.1365-2796.2010.02279.x

[119] Reddy Vanga S, Good M, Howard PA, Vacek JL. Role of vitamin D in cardiovascular health. Am J Cardiol 2010; 10(6): 798-805.

http://dx.doi.org/10.1016/j.amjcard.2010.04.042

[120] Pilz S, van den Hurk K, Nijpels G, Stehouwer CD, Van't Riet $\mathrm{E}$, Kienreich $\mathrm{K}$, et al. Vitamin D status, incident diabetes and prospective changes in glucose metabolism in older subjects: the Hoorn study. Nutr Metab Cardiovasc Dis 2012; 22: 83339. http://dx.doi.org/10.1016/j.numecd.2012.03.008

[121] Hyppönen E, Boucher BJ, Berry DJ, Power C. 25hydroxyvitamin D, IGF-1, and metabolic syndrome at 45 years of age: a cross-sectional study in the 1958 British Birth Cohort. Diabetes 2008; 57(2): 298-305. http://dx.doi.org/10.2337/db07-1122

[122] Wortsman J, Matsuoka LY, Chen TC, Lu Z, Holick MF. Decreased bioavailability of vitamin $\mathrm{D}$ in obesity. Am J Clin Nutr 2000; 72(3): 690-93.

[123] Drincic AT, Armas LA, Van Diest EE, Heaney RP. Volumetric Dilution, Rather Than Sequestration Best Explains the Low Vitamin D Status of Obesity. Obesity (Silver Spring) 2012; 20(7): 1444-48.

http://dx.doi.org/10.1038/oby.2011.404

[124] Kull M, Kallikorm R, Lember M. Body mass index determines sunbathing habits: implications on vitamin $D$ levels. Intern Med J 2009; 39(4): 256-58. http://dx.doi.org/10.1111/j.1445-5994.2009.01900.x 
[125] Shahriari M, Kerr PE, Slade K, Grant-Kels JE. Vitamin D and the skin. Clin Dermatol 2010; 28(6): 663-8.

http://dx.doi.org/10.1016/j.clindermatol.2010.03.030

[126] Hawker NP, Pennypacker SD, Chang SM,. Regulation of human epidermal keratinocyte differentiation by the vitamin $D$ receptor and its coactivators DRIP205, SRC2, and SRC3. J Invest Dermatol 2007; 127(4): 874-80. Epub 2006 Nov 2. http://dx.doi.org/10.1038/sj.jid.5700624

[127] Popadic S, Ramic Z, Medenica L, Mostarica Stojkovic M, Trajković V, Popadic D. Antiproliferative effect of vitamin A and $D$ analogues on adult human keratinocytes in vitro. Skin Pharmacol Physiol 2008; 21(4): 227-34. http://dx.doi.org/10.1159/000135639

[128] Tiberio R, Bozzo C, Pertusi G, Graziola F, Gattoni M, Griffanti $P$, et al. Calcipotriol induces apoptosis in psoriatic keratinocytes. Clin Exp Dermatol 2009; 34(8): e972-4. http://dx.doi.org/10.1111/j.1365-2230.2009.03518.x

[129] Adorini L. Immunomodulatory effects of vitamin $D$ receptor ligands in autoimmune diseases. Int Immunopharmacol 2002; 2: 1017-28.

http://dx.doi.org/10.1016/S1567-5769(02)00049-8

[130] Leone G, Pacifico A. Profile of clinical efficacy and safety of topical tacalcitol. Acta Biomed 2005; 76(1): 13-9.

[131] Fogh K, Kragballe K. New vitamin $D$ analogs in psoriasis. Curr Drug Targets Inflamm Allergy 2004; 3: 199-204. http://dx.doi.org/10.2174/1568010043343930

[132] Segaert S, Duvold LB. Calcipotriol cream: a review of its use in the management of psoriasis. J Dermatolog Treat 2006; 17(6): 327-37.

http://dx.doi.org/10.1080/09546630600999219

[133] Bos JD, Spuls PI. Topical treatments in psoriasis: today and tomorrow. Clin Dermatol 2008; 26: 432-7. http://dx.doi.org/10.1016/i.clindermatol.2007.10.025

[134] Morimoto S, Kumahara Y. A patient with psoriasis cured by 1 alphahydroxyvitamin D3. Med J Osaka Univ 1985; 35: 51-4.

[135] Morimoto S, Yoshikawa K, Kozuka T, Kitano Y, Imanaka S, Fukuo $\mathrm{K}$, et al. Treatment of psoriasis vulgaris with oral 1alpha,25-dihydroxyvitamin D3-report of two cases. J Dermatol 1987; 14: 59-62.

[136] Smith EL, Pincus SH, Donovan L, Holick MF. A novel approach for the evaluation and treatment of psoriasis. J Am Acad Dermatol 1988; 19: 516-28. http://dx.doi.org/10.1016/S0190-9622(88)70207-8

[137] Huckins D, Felson DT, Holick M. Treatment of psoriatic arthritis with oral 1-25 dihydroxyvitamin D3: a pilot study. Arthritis Rheum 1990; 1723-7. http://dx.doi.org/10.1002/art.1780331117

[138] el-Azhary RA, Peters MS, Pittelkow MR, Kao PC, Muller SA. Efficacy of vitamin D3 derivatives in the treatment of psoriasis vulgaris: a preliminary report. Mayo Clin Proc 1993; 68: 835-41. http://dx.doi.org/10.1016/S0025-6196(12)60690-9

[139] Cunningham BB, Landells ID, Langman C, Sailer DE, Paller AS. Topical calcipotriene for morphea/linear scleroderma. $J$ Am Acad Dermatol 1998; 39(2 Pt 1): 211-5. http://dx.doi.org/10.1016/S0190-9622(98)70077-5

[140] Tay YK. Topical calcipotriol ointment in the treatment of morphea. J Dermatolog Treat 2003; 14(4): 219-21. http://dx.doi.org/10.1080/09546630310015449

[141] Kreuter A, Gambichler T, Sauermann K, Jansen T, Altmeyer $P$, Hoffmann K. Extragenital lichen sclerosus successfully treated with topical calcipotriol: evaluation by in vivo confocal laser scanning microscopy. Br J Dermatol 2002; 146(2): 3323.

http://dx.doi.org/10.1046/j.1365-2133.2002.4653 3.x

[142] Marini A, Blecken S, Ruzicka T, Hengge UR. Lichen sclerosus. New aspects of pathogenesis and treatment. Hautarzt 2005; 56(6): 550-5.

http://dx.doi.org/10.1007/s00105-005-0955-0
[143] Gupta S, Saraswat A, Kumar B. Treatment of genital lichen sclerosus with topical calcipotriol. Int J STD AIDS 2005; 16(11): 772-4. http://dx.doi.org/10.1258/095646205774763234

[144] Newton-Bishop JA, Beswick S, Randerson-Moor J, Chang YM, Affleck P, Elliott F, et al. Serum 25- hydroxyvitamin D3 levels are associated with Breslow thickness at presentation and survival from melanoma. J Clin Oncol 2009; 27: 543944.

http://dx.doi.org/10.1200/JCO.2009.22.1135

[145] Randerson-Moor JA, Taylor JC, Elliott F, Chang YM, Beswick $\mathrm{S}$, Kukalizch $\mathrm{K}$, et al. Vitamin $\mathrm{D}$ receptor gene polymorphisms, serum 25-hydroxyvitamin D levels, and melanoma: UK case-control comparisons and a metaanalysis of published VDR data. Eur J Cancer 2009; 45: 3271-81. http://dx.doi.org/10.1016/j.ejca.2009.06.011

[146] Asgari MM, Maruti SS, Kushi LH, White E. A cohort study of vitamin D intake and melanoma risk. J Invest Dermatol 2009; 129: $1675-80$

http://dx.doi.org/10.1038/jid.2008.451

[147] Ratnam AV, Bikle DD, Cho JK. 1,25 dihydroxyvitamin D3 enhances the calcium response of keratinocytes. J Cell Physiol 1999; 178: 188-96. http://dx.doi.org/10.1002/(SICl)10974652(199902)178:2<188::AID-JCP8>3.0.CO;2-4

[148] Kamradt J, Rafi L, Mitschele T, Meineke V, Gärtner BC, Wolfgang $T$, et al. Analysis of the vitamin $D$ system in cutaneous malignancies. Recent Results Cancer Res 2003; 164: 259-69. http://dx.doi.org/10.1007/978-3-642-55580-0 19

[149] Smith EL, Walworth NC, Holick MF. Effect of 1 alpha,25dihydroxyvitamin D3 on the morphologic and biochemical differentiation of cultured human epidermal keratinocytes grown in serum-free conditions. J Invest Dermatol 1986; 86: 709-14.

http://dx.doi.org/10.1111/1523-1747.ep12276343

[150] Gniadecki R. Stimulation versus inhibition of keratinocyte growth by 1,25-dihydroxyvitamin D3: Dependence on cell culture conditions. J Invest Dermatol 1996; 106: 510-6. http://dx.doi.org/10.1111/1523-1747.ep12343866

[151] Smit JV, Cox S, Blokx WA, van de Kerhof PC, de Jongh GJ, de Jong EM. Actinic keratoses in renal transplant recipients do not improve with calcipotriol cream and all-trans retinoic acid cream as monotherapies or in combination during a 6week treatment period. $\mathrm{Br} J$ Dermatol 2002; 147: 816-8. http://onlinelibrary.wiley.com/doi/10.1046/j.13652133.2002.49297.x/abstract

[152] Seckin D, Cerman AA, Yildiz A, Ergun T. Can topical calcipotriol be a treatment alternative in actinic keratoses? A preliminary report. J Drugs Dermatol 2009; 8: 451-4.

[153] van Dam RM, Huang Z, Giovannucci E, Rimm EB, Hunter DJ, Colditz GA, et al. Diet and basal cell carcinoma of the skin in a prospective cohort of men. Am J Clin Nutr 2000; 71 : 135-41. http://ajcn.nutrition.org/content/71/1/135.long

[154] Hunter DJ, Colditz GA, Stampfer MJ, Rosner B, Willett WC, Speizer FE. Diet and risk of basal cell carcinoma of the skin in a prospective cohort of women. Ann Epidemiol 1992; 2: 231-9. http://dx.doi.org/10.1016/1047-2797(92)90055-U

[155] Davies TW, Treasure FP, Welch AA, Day NE. Diet and basal cell skin cancer: results from the EPIC-norfolk cohort. $\mathrm{Br} J$ Dermatol 2002; 146: 1017-22. http://dx.doi.org/10.1046/j.1365-2133.2002.04763.x

[156] Traber MG, Sies H. Vitamin $E$ in humans: demand and delivery. Annu Rev Nutr 1996; 16: 321-47. http://dx.doi.org/10.1146/annurev.nu.16.070196.001541 
[157] Kitagawa M, Mino M. Effects of elevated d-alpha-tocopherol dosage in man. J Nutri Sci Vitaminol (Tokyo) 1989; 35: 13342. http://dx.doi.org/10.3177/jnsv.35.133

[158] Nachbar F, Korting HC. The role of vitamin E in normal and damaged skin. J Mol Med 1995; 73: 7-17. http://dx.doi.org/10.1007/BF00203614

[159] Sies H, Stahl W, Sundquist AR. Antioxidant functions of vitamin: vitamins $\mathrm{E}$ and $\mathrm{C}$, beta-carotene, and other carotenoids. Ann NY Acad Sci 1992; 669: 7-20. http://dx.doi.org/10.1111/j.1749-6632.1992.tb17085.x

[160] Kamal-Eldin A, Appelqvist LA. The chemistry and antioxidant properties of tocopherols and tocotrienols. Lipids 1996; 31 : 671-701.

http://dx.doi.org/10.1007/BF02522884

[161] Tsoureli-Nikita E, Hercogova J, Lotti T, Menchini G. Evaluation of dietary intake of vitamin $\mathrm{E}$ in the treatment of atopic dermatitis: a study of the clinical course and evaluation of the immunoglobulin $E$ serum levels. Int $J$ Dermatol 2002; 41: 146-50. http://dx.doi.org/10.1046/j.1365-4362.2002.01423.x

[162] Pathak MA, Carbonare MD. Photoaging and the role of mammalian skin superoxide dismutase and antioxidants. Photochem Photobiol 1988; 47: 7S.

[163] Bissett DL, Majeti S, Fu JJ, McBride JF, Wyder WE. Protective effect of topically applied conjugated hexadienes against ultraviolet radiation-induced chronic skin damage in the hairless mouse. Photodermatol Photoimmunol Photomed 1990; 7: 63-7.

[164] Beijersbergen van Henegouwen GMJ, Junginger HE, de Vries H. Hydrolysis of RRR- $\alpha$ tocopheryl acetate (vitamin E acetate) in the skin and its UV protecting activity (an in vivo study with the rat). J Photochem Photobiol B Biol 1995; 29: 45-51. http://dx.doi.org/10.1016/1011-1344(95)90251-1

[165] Bissett DL, Chatterjee R, Hannon DP. Protective effect of a topically applied anti-oxidant plus an anti-inflammatory agent against ultraviolet radiation-induced chronic skin damage in the hairless mouse. J Soc Cosmet Chem 1992; 43: 85-92.

[166] Bissett DL, Chatterjee R, Hannon DP. Photoprotective effect of superoxide-scavenging antioxidants against ultraviolet radiationinduced chronic skin damage in the hairless mouse. Photodermatol Photoimmunol Photomed 1990; 7: 56-62.

[167] Jurkiewicz BA, Bissett DL, Buettner GR. Effect of topically applied tocopherol on ultraviolet radiation-mediated free radical damage in skin. J Invest Dermatol 1995; 104: 484-8. http://dx.doi.org/10.1111/1523-1747.ep12605921

[168] Burke KE, Clive J, Combs GF Jr, Commisso J, Keen CL, Nakamura RM. Effects of topical and oral vitamin $E$ on pigmentation and skin cancer induced by ultraviolet irradiation in Skh: 2 hairless mice. Nutr Cancer 2000; 38: 8797.

http://dx.doi.org/10.1207/S15327914NC381 13

[169] Record IR, Dreosti IE, Konstantinopoulos M, Buckley RA. The influence of topical and systemic vitamin $E$ on ultraviolet light-induced skin damage in hairless mice. Nutr Cancer 1991; 16: 219-26.

http://dx.doi.org/10.1080/01635589109514160

[170] Trevithick JR, Xiong H, Lee S, Shum DT, Sanford SE, Karlik SJ, et al. Topical tocopherol acetate reduces post-UVB, sunburn-associated erythema, edema, and skin sensitivity in hairless mice. Arch Biochem Biophys 1992; 296: 575-82. http://dx.doi.org/10.1016/0003-9861(92)90613-2

[171] Trevithick JR, Shum DT, Redae S, Mitton KP, Norley C, Karlik SJ, et al. Reduction of sunburn damage to skin by topical application of vitamin $\mathrm{E}$ acetate following exposure to ultraviolet $B$ radiation: effect of delaying application or of reducing concentration of vitamin $\mathrm{E}$ acetate applied. Scan Microsc 1993; 7: 1269-81.
[172] Brenner S, Horwitz C. Possible nutrient mediators in psoriasis and seborrheic dermatitis. II. Nutrient mediators: essential fatty acids; vitamins $A, E$ and D; vitamins B1, B2, B6, niacin and biotin; vitamin C selenium; zinc; iron. World Rev Nutr Diet 1988; 55: 165-82.

[173] Arutiunov Vla, Gutman SE. Experience in treating certain alopecias with liquid nitrogen and vitamins $A$ and $E$. Sov Med 1972; 35(4): 126-30.

[174] McGee P. Vitamin E and pruritus. Can Nurse 2001; 97(1): 8.

[175] Budeguer MA. Treatment of genital pruritus with vitamin E Dia Med 1950; 22(66): 2772-6.

[176] Parsa FD. Vitamin E: facts and fallacies. Plast Reconstr Surg 1988; 81: 300-1. http://dx.doi.org/10.1097/00006534-198802000-00045

[177] Lee M. An investigation into the value of d,l-alpha-tocopheryl acetate (vitamin $\mathrm{E}$ ) in the treatment of gravitational ulcers. $\mathrm{Br}$ J Dermatol 1953; 65: 131-8. http://dx.doi.org/10.1111/j.1365-2133.1953.tb15677.x

[178] Musalmah M, Fairuz AH, Gapor MT, Ngah WZ. Effect of vitamin $\mathrm{E}$ on plasma malondialdehyde, antioxidant enzyme levels and the rates of wound closures during wound healing in normal and diabetic rats. Asia Pac J Clin Nutr 2002; 11(Suppl 7): 448-51.

http://dx.doi.org/10.1046/j.1440-6047.11.s.7.6.x

[179] Gray M. Does oral supplementation with vitamins $A$ or $E$ promote healing of chronic wounds? J Wound Ostomy Continence Nurs 2003; 30(6): 290-4. http://www. sciencedirect.com/science/article/pii/S1071575403005163

[180] Rashid SA, Halim AS, Muhammad NA. The effect of vitamin $\mathrm{E}$ on basic fibroblast growth factor level in human fibroblast cell culture. Med J Malaysia 2008; 63(Suppl A): 69-70.

[181] Baumann LS, Spencer J. The effects of topical vitamin E on the cosmetic appearance of scars. Dermatol Surg 1999; 25(4): 311-15. http://dx.doi.org/10.1046/j.1524-4725.1999.08223.x

[182] Chang CW, Ries WR. Nonoperative techniques for scar management and revision. Facial Plast Surg 2001; 17(4): 283-288.

http://dx.doi.org/10.1055/s-2001-18826

[183] Palmieri B, Gozzi G, Palmieri G. Vitamin E added silicon gel sheets for treatment of hypertrophic scars and keloids. Int $\mathrm{J}$ Dermatol 1995; 34(7): 506-509. http://dx.doi.org/10.1111/j.1365-4362.1995.tb00628.x

[184] Lopez-Torres M, Thiele JJ, Shindo Y, Han D, Packer L. Topical application of alpha-tocopherol modulates the antioxidant network and diminishes ultravioletinduced oxidative damage in murine skin. $\mathrm{Br} \mathrm{J}$ Dermatol 1998; 138: 207-15. http://dx.doi.org/10.1046/j.1365-2133.1998.02062.x

[185] Yuen KS, Halliday GM. Alpha-tocopherol, an inhibitor of epidermal lipid peroxidation, prevents ultraviolet radiation from suppressing the skin immune system. Photochem Photobiol 1997; 65: 587-92. http://dx.doi.org/10.1111/j.1751-1097.1997.tb08610.x

[186] Gensler HL, Magdaleno M. Topical vitamin E inhibition of immunosuppression and tumorigenesis induced by ultraviolet irradiation. Nutr Cancer 1991; 15: 97-106.

http://dx.doi.org/10.1080/01635589109514117

[187] Steenvoorden DP, Beijersbergen van Henegouwen GMJ. The use of endogenous antioxidants to improve photoprotection. J Photochem Photobiol B 1997; 41 (1-2): 110. http://dx.doi.org/10.1016/S1011-1344(97)00081-X

[188] Kagan V, Witt E, Goldman R, Scita G, Packer L. Ultraviolet light-induced generation of vitamin $E$ radicals and their recycling. A possible photosensitizing effect of vitamin $E$ in skin. Free Radic Res Commun 1992; 16 (1): 51-64. http://dx.doi.org/10.3109/10715769209049159 
[189] Jurkiewicz BA, Bissett DL, Buettner GR. Effect of topically applied tocopherol on ultraviolet radiation-mediated free radical damage in skin. J Invest Dermatol 1995; 104 (4): 4848.

http://dx.doi.org/10.1111/1523-1747.ep12605921

[190] Beijersbergen van Henegouwen GM, Junginger HE, de Vries $\mathrm{H}$. Hydrolysis of RRR-alpha-tocopheryl acetate (vitamin E acetate) in the skin and its UV protecting activity (an in vivo study with the rat). J Photochem Photobiol B 1995; 29(1): 4551.

http://dx.doi.org/10.1016/1011-1344(95)90251-1

[191] Chung CJ, Pu YS, Chen YT, Su CT, Wu CC, Shiue HS, et al. Protective effects of plasma alpha-tocopherols on the risk of inorganic arsenic-related urothelial carcinoma. Sci Total Environ 2011; 409(6): 1039-45.

http://dx.doi.org/10.1016/i.scitotenv.2010.11.037

[192] Jeong NH, Song ES, Lee JM, Lee KB, Kim MK, Cheon JE, et al. Plasma carotenoids, retinol and tocopherol levels and the risk of ovarian cancer. Acta Obstet Gynecol Scand 2009; 88(4): 457-62.

http://dx.doi.org/10.1080/00016340902807215

[193] Liang D, Lin J, Grossman HB, Ma J, Wei B, Dinney CP, Wu $X$. Plasma vitamins $E$ and $A$ and risk of bladder cancer: $a$ case-control analysis. Cancer Causes Control 2008; 19(9): 981-92.

http://dx.doi.org/10.1007/s10552-008-9165-2

[194] Jenab M, Riboli E, Ferrari P, Friesen M, Sabate J, Norat T, et al. Plasma and dietary carotenoid, retinol and tocopherol levels and the risk of gastric adenocarcinomas in the European prospective investigation into cancer and nutrition. Br J Cancer 2006; 95(3): 406-15. http://dx.doi.org/10.1038/sj.bjc.6603266

[195] Burgess JF, Pritchard JE. Tocopherols. Arch Dermatol Syph 1948; 57: 953-64. http://dx.doi.org/10.1001/archderm.1948.01520190032005

[196] Grubb E. Our experience with vitamin E treatment. Acta Derm Venereol (Stockh) 1952; 32: 256-8.

[197] Welch AL. Treatment by combined use of massive amounts of pantothenic acid and vitamin $\mathrm{E}$ in lupus erythematosus. Arch Dermatol 1954; 70(2): 181-98.

http://dx.doi.org/10.1001/archderm.1954.01540200041004

[198] Ayres S Jr, Mihan R. Lupus erythematosus and vitamin E: an effective and non-toxic therapy. Cutis 1979; 23: 49-53.

[199] Ayres S Jr, Mihan R. Vitamin E and dermatology. Cutis 1975; 16: 1017-21.

[200] Norton L. Further observations on the yellow nail syndrome with therapeutic effects of oral alpha-tocopherol. Cutis 1985; 36: 457-62.
[201] Ayres S Jr, Mihan R. Yellow nail syndrome: response to vitamin E. Arch Dermatol 1973; 108: 267-8.

http://dx.doi.org/10.1001/archderm.1973.01620230063024

[202] Machlin LJ, Brin M. In: Altin-Fluter R, Krichevsky D, Eds. Nutrition and adult micronutrients. New York: Plenum Press 1980; p. 261.

[203] Shearer MJ, Fu X, Booth SL. Vitamin K nutrition, metabolism, and requirements: current concepts and future research. Adv Nutr. 2012 Mar 1; 3(2): 182-95. http://dx.doi.org/10.3945/an.111.001800

[204] Ferland G. The discovery of vitamin $K$ and its clinical applications. Ann Nutr Metab 2012; 61(3): 213-8. http://dx.doi.org/10.1159/000343108

[205] Price CT, Langford JR, Liporace FA. Essential Nutrients for Bone Health and a Review of their Availability in the Average North American Diet. Open Orthop J 2012; 6: 143-9. http://www.ncbi.nlm.nih.gov/pmc/articles/PMC3330619/

[206] Vermeer C. Vitamin K. the effect on health beyond coagulation - an overview. Food Nutr Res 2012; 56. Epub 2012 Apr 2. http://www.ncbi.nlm.nih.gov/pmc/articles/ PMC3321262/

[207] Hogenbirk K, Peters M, Bouman P, Sturk A, Büller HA. The effect of formula versus breast feeding and exogenous vitamin $\mathrm{K} 1$ supplementation on circulating levels of vitamin $\mathrm{K} 1$ and vitamin K-dependent clotting factors in newborns. Eur J Pediatr 1993; 152: 72-4. http://dx.doi.org/10.1007/BF02072521

[208] Lulseged S. Haemorrhagic disease of the newborn: a review of 127 cases. Ann Trop Paediatr 1993; 13: 331-6.

[209] Loughnan P, McDougall P. Epidemiology of late onset haemorrhagic disease: a pooled data analysis. J Paediatr Child Health 1993; 29: 177-81. http://dx.doi.org/10.1111/j.1440-1754.1993.tb00480.x

[210] Widdershoven J, van Munster P, De Abreu R, Bosman H, van Lith $\mathrm{T}$, van der Putten-van Meyel $\mathrm{M}$, et al. Four methods compared for measuring des-carboxy-prothrombin (PIVKAII). Clin Chem 1987; 33 (11): 2074-8. http://www.clinchem. org/content/33/11/2074.long

[211] Wojcik A, Atkins M, Mager DR. Dietary intake in clients with chronic wounds. Can J Diet Pract Res 2011; 72(2): 77-82. http://dx.doi.org/10.3148/72.2.2011.77

[212] Yoshikawa H, Yamazaki S, Watanabe T, Abe T. Vitamin K deficiency in severely disabled children. J Child Neurol 2003; 18(2): 93-7. http://dx.doi.org/10.1177/08830738030180020801 